\title{
PENGGUNAAN BAHASA OLEH K.H. ANWAR ZAHID DALAM CERAMAH AGAMA
}

\section{LANGUAGE USED IN RELIGIOUS SPEECHES BY K.H. ANWAR ZAHID}

\author{
Ema Yuniar', Bambang Wibisono ${ }^{2 *}$, A. Erna Rochiyati S. ${ }^{3}$ \\ ${ }^{1}$ Alumni Fakultas Ilmu Budaya, Universitas Jember \\ ${ }^{2,3}$ Fakultas Ilmu Budaya, Universitas Jember \\ *Corresponding Author:bangwib@yahoo.co.id \\ Informasi Artikel:
}

Dikirim: 23/12/2018; Direvisi: 3/01/2019; Diterima: 19/02/2019

\begin{abstract}
Religious speech (Islam) is a form of oral language used by a preacher to preach or communicate public directly. The purpose of this study is to describe the use of language in religious lectures by K.H. Anwar Zahid, one of the well-known religious preachers in East Java, also described the factors why he chooses the language in his preaching. Data is obtained by listening technique by applying SLBC (simak libat bebas cakap) method. In this method the researchers only acts as an observer to their informants. They do not involve in a speech event even though in the language was being scrutinized. SBLC is used to listen to the language used in religious sermon by K.H. Anwar Zahid. The data are taken from You tube channel. We use extra lingual equivalent method to analyze the factors underlying the use of language in religious speeches by K.H. Anwar Zahid. The results showed that K.H. Anwar always did code-mixing events, never using a single language in his preaching. Factors behind his choosing language are place, audience or target audience.
\end{abstract}

Keywords: Anwar Zahid, code-mixing, code switching, religious preaching, target

\begin{abstract}
Abstrak
Ceramah agama (Islam) merupakan salah satu bentuk bahasa lisan yang digunakan oleh seorang mubalig untuk berdakwah atau berkomunikasi langsung dengan khalayak. Tujuan penelitian ini mendeskripsikan penggunaan bahasa dalam ceramah agama oleh K.H. Anwar Zahid, salah seorang penceramah agama yang terkenal di Jawa Timur, serta mendeskripsikan faktor-faktor yang melatarbelakangi penggunaan bahasa dalam ceramahnya. Penyediaan data dalam penelitian ini menggunakan teknik simak, yaitu teknik Simak Bebas Libat Cakap (SBLC). SBLC digunakan untuk menyimak tuturan penggunaan bahasa ceramah agama oleh K.H. Anwar Zahid yang bersumber dari situs youtube. Analisis data menggunakan metode padan intralingual untuk menganalisis data bahasa yang digunakan, dan metode padan ekstralingual untuk menganalisis faktor-faktor yang melatarbelakangi penggunaan bahasa dalam ceramah agama oleh K.H. Anwar Zahid. Hasil penelitian menunjukkan bahwa K.H. Anwar selalu melakukan peristiwa campur kode, tidak pernah menggunakan tunggal bahasa dalam ceramahnya. Faktorfaktor yang melatarbelakangi penggunaan bahasa oleh K.H. Anwar Zahid adalah faktor tempat dan partisipan atau khalayak sasaran.
\end{abstract}

Kata kunci: Anwar Zahid, campur kode, alih kode, ceramah agama, segmen 


\section{PENDAHULUAN}

K.H. Anwar Zahid, yang nama aslinya adalah Ahmad Anwar Zahid, lahir di Bojonegoro, 11 Maret 1974, adalah seorang dai atau penceramah yang terkenal hingga saat ini. Sejak kecil beliau sudah terbiasa hidup di pondok, pondok pesantren yang pertama kali beliau masuki adalah Pondok Pesantren Langitan di Tuban, lalu setelah sekian lama beliau belajar di pondok pesantren tersebut, beliau berpindah ke APTQ (Asrama Pesantren Ta'limul Quran) di Bungah, Gresik yang memberi pembelajaran khusus tentang Tahfidzul Quran (hafalan Quran), sehingga beliau berhasil menjadi seorang Huffadz (orang yang lulus hafalan Al-Qur'an) sejak masa remaja.

Sampai sekarang beliau tinggal di Kecamatan Kanor, Kabupaten Bojonegoro, Jawa Timur. Setiap hari rata-rata beliau harus mengisi tiga sampai empat jadwal pengajian di berbagai daerah, biasanya adalah pada waktu pagi, sore, dan malam, bahkan hingga pukul 01.00 dini hari. Untuk dapat mengundang beliau pengundang harus mengantre selama dua tahun. Ceramah beliau sangat digemari oleh semua kalangan masyarakat. Bahasa yang digunakan selalu mengena di hati para jamaah dan selalu diiringi humor-humor yang bermakna. Beliau dalam menyindir perilaku dan sifat seseorang yang biasa terjadi di dalam sebuah masyarakat dapat disindir dengan tepat, sehingga para jamaah pun hanya dapat tersenyum dan menyadari akan kebenaran dari pernyataan yang beliau sampaikan. Sesuatu yang menjadi pokok inti ceramah secara tidak sadar diterima oleh khalayak sasarannya dengan tersenyum. Masyarakat menyukai materi pengajian yang disampaikan dengan bahasa yang khas dan melalui humor-humor.

Video-video cuplikan pengajian beliau telah banyak tersebar dan terekspos di media sosial, salah satunya adalah di YouTube dan Instagram(@khanwarzahid.id). Beliau jarang muncul di layar TV, namun jadwal pengajian beliau sangat padat. Pamflet-pamflet pengajian beliau tersebar luas di berbagai daerah, khususnya di Jawa Timur dan Jawa Tengah.

Selain mengisi pengajian di Jawa, beliau juga sering mengisi pengajian di mancanegara, seperti Hong Kong, Korea Selatan, dan Malaysia. Bahkan, hampir setiap bulan beliau mengisi pengajian di sana. Terdapat pengajian rutin di kediaman beliau, yaitu setiap Minggu Kliwon yang pengajian itu diberi nama Jamaah Maqoman Mahmudah.

Beliau juga memiliki Yayasan Pondok yang berada tepat di samping kediaman beliau, bernama Yayasan Pondok Pesantren Sabilun Najah. Dalam pondok pesantren ini terdapat jenjang pendidikan MTs dan MA. Hal yang menarik adalah para santri yang menuntut ilmu di pondok tersebut seluruh biaya sehari-harinya ditanggung penuh oleh pihak pondok.

Bahasa yang digunakan oleh beliau menarik dan perlu diteliti, sehingga diketahui ciriciri bahasa yang digunakan. Hasil penelitian ini penting sebagai masukan dan contoh bagi para calon penceramah agar ceramahnya menarik khalayak sasaran yang diberi ceramah.

Penggunaan bahasa dalam ceramah agama sudah dilakukan oleh peneliti sebelumnya. Misalnya penelitian yang dilakukan oleh Sutardi (1994), Khadafi (2009), dan Rahayuningsih (2013). Sutardi meneliti pemakaian bahasa dalam ceramah agama oleh K.H. Zainuddin M.Z., Khadafi meneliti penggunakan bahasa ceramah agama dalam Majelis Sholawatan AlGhofilin, dan Rahayuningsih meneliti penggunaan bahasa dalam ceramah agama oleh K.H. Anwar Zahid dari aspek pragmatik. Penggunaan bahasa dalam ceramah agama oleh K.H. Anwar Zahid belum pernah diteliti dari aspek sosiolinguistik. 
Dalam kaitannya dengan penggunaan bahasa, pemilihan bahasa oleh seseorang biasanya ada tiga jenis, yaitu dengan melakukan campur kode, alih kode, dan tunggal bahasa (Chaer dan Agustina, 2014:154). Campur kode artinya penutur dan lawan tutur menggunakan satu bahasa tertentu dengan mencampurkan serpihan-serpihan bahasa lain. Alih kode artinya apabila seseorang menggunakan satu bahasa pada satu keperluan dan menggunakan bahasa lain pada satu keperluan yang lain. Tunggal bahasa artinya penggunaan satu bahasa tunggal secara keseluruhan dari awal hingga akhir peristiwa tutur tanpa adanya pergantian kode, baik berupa alih kode maupun campur kode. Penutur maupun petutur tetap menggunakan satu kode bahasa sejak awal pertuturan sampai akhir pertuturan. Dikaji dari faktor yang menentukan, pilihan bahasa biasanya terikat oleh lokasi, topik, dan partisipan. Dalam kaitan ini, menurut Hymes (dalam Schiffrin, 1994) ada delapan komponen yang mengikat pemilihan bahasa oleh seseorang dalam berbahasa, yaitu (1) tempat dan suasana tutur (setting and scenes), (2) peserta tutur (participant), (3) tujuan tutur (ends), (4) pokok tuturan (act sequences), (5) nada tutur (keys), (6) sarana tutur (instrumentalities), (7) norma tutur (norms), dan (8) jenis tutur (genres).

Berdasarkan alasan yang telah dikemukakan, peneliti tertarik dan merasa perlu meneliti bahasa yang digunakan K.H. Anwar Zahid dalam memberikan pengajian umum. Tujuan penelitian ini meliputi: (1) wujud pemilihan bahasa yang digunakan oleh K.H. Anwar Zahid, dalam ceramah agama atau pengajian umum, yang mencakup campur kode, alih kode, dan struktur bahasa, dan (2) faktor-faktor yang melatarbelakangi digunakannya bahasa atau varian bahasa tertentu oleh K.H. Anwar Zahid dalam ceramahnya, yang hasilnya tersaji dalam artikel ini.

\section{METODE}

Metode yang digunakan dalam penelitian ini adalah metode deskriptif kualitatif. Penyediaan data yang digunakan dalam penelitian ini adalah metode simak, yaitu menyimak tuturan penggunaan bahasa dalam ceramah agama yang digunakan oleh K.H. Anwar Zahid dalam ceramahnya yang bersumber dari situs Youtube. Dalam kaitannya dengan metode simak, Sudaryanto (1993:133-134) menjelaskan bahwa metode simak terdiri atas teknik Simak Libat Cakap (SLC) dan teknik Simak Bebas Libat Cakap (SBLC). Teknik Simak Libat Cakap (SLC) adalah teknik pengamatan secara langsung. Peneliti berperan sebagai mitra tutur yang mengamati, mencatat, merekam, dan mewawancarai informan. Teknik Simak Bebas Libat Cakap (SBLC) adalah teknik pengamatan secara tidak langsung, yaitu peneliti tidak terlibat dalam dialog, konversasi, atau imbal wicara dengan informan. Teknik dasar dari metode simak yaitu teknik sadap. Teknik sadap merupakan kegitan penyadapan penggunaan bahasa oleh informan.

Dalam kaitannya dengan penelitian ini, peneliti menggunakan Teknik Simak Bebas Libat Cakap (TSBLC) karena data penelitian ini bersumber dari situs Youtube. Data penelitian ini adalah kode-kode bahasa yang ada pada tuturan K.H Anwar Zahid dalam memberikan ceramah pada pengajian umum. Selanjutnya, data yang didapatkan, yang bersumber dari situs Youtube, yang berupa tuturan penggunaan bahasa dalam ceramah agama oleh K.H. Anwar Zahid ditranskripsi.

Menurut Sudaryanto (1993:136) transkripsi yang digunakan dapat dipilih dari antara yang ada berikut, bergantung pada jenis objek sasarannya, yaitu transkripsi ortografis, 
fonemis, dan fonetis. Transkripsi fonetis adalah transkripsi yang berusaha menggambarkan semua bunyi bahasa secara teliti baik yang membedakan fonem atau tidak. Pada penelitian ini, transkripsi data yang digunakan adalah transkripsi ortografis dan fonetis, yaitu data yang berupa tuturan ceramah Agama K.H. Anwar Zahid ditranskripsi, pertama secara ortografis (menurut ejaan yang benar), kemudian ditambah transkripsi fonetis jika bahasa dalam tuturan tersebut tidak menggunakan bahasa Indonesia. Dengan demikian, transkripsi data yang digunakan adalah transkripsi fonetis jika terdapat data bahasa selain bahasa Indonesia.

Analisis data dilakukan menggunakan metode padan intralingual. Metode padan intralingual digunakan untuk menganalisis permasalahan yang berhubungan dengan wujud penggunaan bahasa ceramah K.H. Anwar Zahid. Teknik metode padan intralingual dibagi menjadi tiga, yaitu (1) teknik hubung banding menyamakan (HBS), (2) teknik hubung banding membedakan (HBB), dan teknik hubung banding menyamakan hal pokok (HBSP), yaitu teknik yang bertujuan untuk mencari kesamaan hal pokok dari pembedaan dan penyamaan yang dilakukan dengan menerapkan teknik HBS dan HBB. Tujuan akhir dilakukannya analisis hubung banding menyamakan atau membedakan adalah untuk menentukan kesamaan pokok di antara data yang diperbandingkan. Hubung banding menyamakan dan membedakan yang dimaksud adalah data yang termasuk campur kode dan tunggal bahasa dianalisis dengan cara menyamakan apakah tergolong campur kode atau tunggal bahasa dan membedakan data tersebut dengan analisis sesuai landasan teori yang berkaitan dengan campur kode dan tunggal bahasa. Pelaksanaan metode padan intralingual juga menggunakan kamus bahasa Indonesia (Badan Pengembangan dan Pembinaan Bahasa, 2016), kamus bahasa Jawa (Purwadi, 2004), dan kamus bahasa Arab (Al-Munawwir, 2002).

Selain metode padan intralingual, peneliti menggunakan metode padan ekstralingual untuk menjawab permasalahan yang kedua. Metode padan ekstalingual adalah metode yang digunakan untuk menganalisis unsur yang bersifat ekstralingual, seperti menghubungkan masalah bahasa dengan hal yang berada di luar bahasa (Mahsun, 2005:114). Metode padan ekstralingual digunakan untuk memecahkan masalah yang kedua dengan menggunakan teknik hubung banding menyamakan (HBS) dan teknik hubung banding membedakan (HBB). HBS dan HBB digunakan untuk mengetahui faktor-faktor yang melatarbelakangi penggunaan bahasa dalam ceramah agama oleh K.H. Anwar Zahid. Padan ekstralingual yang dimaksud mencakup: (1) tempat dan suasana, (2) peserta tutur (partisipant), (3) tujuan tuturan, (4) pokok tuturan, (5) nada tuturan, (6) sarana tutur, (7) norma tutur, dan (8) jenis tutur. Dalam penelitian ini, hasil analisis data disajikan atau dipaparkan dengan menggunakan metode informal. Metode informal dilakukan dengan cara menggunakan kata-kata biasa, yaitu dengan cara memaparkan bahasa yang digunakan oleh K.H. Anwar Zahid dalam ceramahnya secara naratif.

\section{HASIL DAN PEMBAHASAN}

Secara umum bahasa yang digunakan oleh K.H. Anwar Zahid dalam ceramahceramahnya adalah bahasa Indonesia. Namun, tidak secara keseluruhan menggunakan bahasa Indonesia. Dalam ceramahnya kadang-kadang penceramah memasukkan unsur bahasa lain. Unsur bahasa lain tersebut adalah bahasa Jawa Ngoko, bahasa Jawa Krama, bahasa Arab dan bahasa asing. Dalam ceramahnya, K.H Anwar Zahid tidak pernah menggunakan satu bahasa atau tunggal bahasa. Bahasa yang digunakan oleh K.H. Anwar Zahid selalu campuran. 
Pengunaan bahasa Arab, misalnya, ada pada segmen pembukaan ceramah dan segmen doa penutup. Penggunaan bahasa Indonesia ketika penceramah menyampaikan isi ceramah kepada khalayaknya. Penggunaan bahasa asing, ketika penceramah menyapa khalayak. Bahasa yang tampak khas adalah digunakannya unsur dasar bahasa daerah (Jawa) dan imbuhan bahasa Indonesia. Selain itu, K.H. Anwar Zahid menggunakan bahasa berirama. Secara khusus bahasa yang digunakan oleh K.H. Anwar Zahid dalam ceramahnya dapat dideskripsikan sebagai berikut.

\section{Penggunaan Bahasa oleh K.H Anwar Zahid dalam Ceramah Agama}

Dari data yang berhasil dihimpun dapat diketahui bahwa bahasa yang digunakan dalam ceramah agama oleh K.H. Anwar Zahid pada umumnya menggunakan bahasa Indonesia dan bahasa Arab. Bahasa Indonesia terutama digunakan untuk menyampaikan isi ceramah. Penggunaan bahasa Arab terutama pada segmen pembuka ceramah dan segmen doa penutup ceramah. Selain itu, di dalam memberikan ceramah beliau sering kali menyelipkan unsur-unsur bahasa lain. Unsur bahasa lain tersebut adalah bahasa Jawa Ngoko, bahasa Jawa Krama, bahasa Arab, dan bahasa asing. Dengan demikian, dalam bahasa yang digunakan oleh K.H. Anwar Zahid ketika berceramah terdapat peristiwa campur kode dan alih kode.

\section{Penggunaan Campur Kode Bahasa Jawa}

Campur kode adalah terjadinya pencampuran penggunaan bahasa lain dalam pemakaian satu bahasa tertentu. Demikian juga, pada penggunaan bahasa ceramah agama oleh K.H. Anwar Zahid, dalam menyampaikan ceramahnya kadang-kadang menyelipkan unsurunsur bahasa lain seperti bahasa Jawa Ngoko, bahasa Jawa Krama dan bahasa Arab, sehingga penggunaan bahasa ceramah agama yang dilakukan oleh K.H. Anwar Zahid terjadi peristiwa campur kode yang mencakup campur kode bahasa Jawa dan bahasa Arab. Penggunaan campur kode tersebut tampak pada kutipan data berikut ini.

Konteks: Tuturan ini disampaikan oleh K.H. Anwar Zahid dalam rangka Pengajian Umum untuk Memperingati Maulid Nabi SAW yang diselenggarakan oleh Remaja Masjid Baiturrohim, pada tanggal 8 Januari 2018 bertempat di Desa Siwalan Panji, Kecamatan Buduran, Kabupaten Sidoarjo.

Tuturan: "Saya ulang, ayo kita berusaha maksimal untuk menjadi orang yang ketiadaannya selalu dicari, kehadirannya selalu dinanti, koyok aku" [ ... kəyə? aku].

'Saya ulang, ayo kita berusaha maksimal untuk menjadi orang yang ketiadaannya selalu dicari, kehadirannya selalu dinanti, seperti saya'.

Data tersebut memperlihatkan bahwa ada peristiwa campur kode yang dilakukan oleh K.H. Anwar Zahid dalam ceramahnya. Dalam kode bahasa Indonesia, "Saya ulang, ayo kita berusaha maksimal untuk menjadi orang yang ketiadaannya selalu dicari, kehadirannya selalu dinanti..." diselipkan penggunaan kode bahasa Jawa, yaitu "koyok aku". Menurut Kamus bahasa Jawa (Purwadi, 2004:232) koyok dalam bahasa Indonesia artinya 'seperti' dan menurut Kamus Bahasa Jawa (Purwadi, 2004:11) aku dalam bahasa Indonesia artinya 'saya'. Artinya, K.H. Anwar Zahid dalam ceramahnya melakukan campur kode bahasa Jawa ke dalam bahasa Indonesia. Hal ini ditandai oleh digunakannya frasa bahasa Jawa koyok aku ke 
dalam bahasa Indonesia yang digunakan. Dalam hal ini bahasa Jawa yang digunakan oleh K.H. Anwar Zahid adalah bahasa Jawa ragam Ngoko. Berikut adalah faktor-faktor yang menyebabkan K.H. Anwar Zahid di dalam menyampaikan ceramahnya melakukan campur kode bahasa Jawa Ngoko. Pertama, dikarenakan penceramah beretnik Jawa dan khalayak mayoritas beretnik Jawa. Oleh karena itu, ketika penceramah berceramah kadang-kadang memasukkan unsur bahasa lain dan yang dipilih adalah bahasa Jawa. Kedua, penceramah menggunakan bahasa Jawa Ngoko karena penceramah mencontohkan dirinya sendiri. Penceramah tidak memakai bahasa Jawa Krama seperti kados kulo, tetapi memakai bahasa Jawa Ngoko koyok aku karena konteksnya kelakar. Jika bukan kelakar, maka kesannya adalah sombong yang justru dihindari dalam agama Islam. K.H. Anwar Zahid dalam ceramahnya dikenal suka berkelakar. Hal itu yang membuat beliau disukai oleh khalayak. Ketiga, penceramah juga ingin lebih mendekatkan dirinya kepada khalayak, sehingga tidak ada jarak antara penceramah dan khalayak.

\section{Penggunaan Campur Kode Bahasa Arab}

Berdasarkan data yang didapatkan ditemukan peristiwa campur kode bahasa Arab ke dalam bahasa Indonesia dalam penggunaan bahasa ceramah agama oleh K.H Anwar Zahid. Hal ini seperti tampak pada kutipan data berikut.

Konteks: Tuturan ini disampaikan oleh K.H. Anwar Zahid dalam rangka Pengajian Umum untuk Memperingati Maulid Nabi SAW yang diselenggarakan oleh Remaja Masjid Baiturrohim, pada tanggal 8 Januari 2018 bertempat di Desa Siwalan Panji, Kecamatan Buduran, Kabupaten Sidoarjo.

Tuturan: "Malam hari ini kita langsung ke poin saja. Rasullulah itu uswatun hasanah [ ... uswatun hasanah] teladan kebaikan dalam seluruh aspek kehidupan manusia.

'Malam hari ini kita langsung ke poin saja. Rasullulah itu panutan baik, teladan kebaikan dalam seluruh aspek kehidupan manusia'.

Data tersebut merupakan peristiwa campur kode yang dilakukan oleh K.H. Anwar Zahid dalam ceramahnya. Kode bahasa Indonesia Malam hari ini kita langsung ke poin saja. Rasullah itu,... uswatun hasanah dalam seluruh aspek kehidupan manusia dan kode bahasa Arab uswatun hasanah. Menurut Kamus bahasa Arab (Al-Munawwir, 2002:25) uswatun dalam bahasa Indonesia artinya 'panutan' dan menurut Kamus Bahasa Arab (Al-Munawwir, 2002:265) hasanah dalam bahasa Indonesia artinya 'baik' sehingga uswatun hasanah artinya 'panutan baik'. Artinya, K.H. Anwar Zahid dalam ceramahnya melakukan campur kode bahasa Arab ke dalam bahasa Indonesia, karena ceramah ini adalah ceramah agama Islam. Tujuan beliau melakukan campur kode bahasa Arab untuk meyakinkan kepada khalayak bahwa penceramah berceramah yang sumbernya Al-Qur'an berbahasa Arab, sehingga kata uswatun hasanah sangat ditekankan yang kemudian diulang lagi dalam bahasa Indonesia yang artinya sama. Faktor-faktor yang menyebabkan K.H. Anwar Zahid di dalam menyampaikan ceramahnya melakukan campur kode bahasa Arab karena memang penceramah beragama Islam dan khalayak juga beragama Islam jadi penceramah memasukkan unsur bahasa lain dan yang dipilih yaitu bahasa Arab meskipun tidak semua khalayak mengerti arti bahasa Arab tersebut, tetapi penceramah memberikan terjemahan atau 
arti kepada khalayak. Selain itu, penceramah dalam berceramah berpedoman kitab Al-Qur'an dan hadis sebagai sumber berceramah yang aslinya ditulis dalam bahasa Arab.

\section{Penggunaan Alih Kode}

Selain melakukan campur kode, K.H Anwar Zahid dalam ceramahnya juga melakukan alih kode, yaitu beralih menggunakan bahasa tertentu dalam segmen tertentu ceramahnya dan menggunakan bahasa tertentu yang lain dalam segmen ceramah yang lain. Misalnya, pada segmen penyampaian isi ceramah, menggunakan bahasa Indonesia, tetapi pada segmen pembuka ceramah, dan doa penutup beralih menggunakan bahasa Arab, dan segmen menyapa beralih menggunakan bahasa Jawa atau bahasa asing. Penggunaaan bahasa Indonesia pada ceramah agama oleh K.H. Anwar Zahid tampak pada kutipan berikut.

Konteks: Tuturan ini disampaikan oleh K.H. Anwar Zahid dalam rangka Pengajian Umum untuk Memperingati Maulid Nabi SAW yang diselenggarakan oleh Remaja Masjid Baiturrohim, pada tanggal 8 Januari 2018 bertempat di Desa Siwalan Panji, Kecamatan Buduran, Kabupaten Sidoarjo.

Tuturan: Pejabat pemerintah Bapak Camat, bersama jajaran Muspika, Bapak Kapolsek berikut para anggota, Bapak Komandan Ramil juga para anggota yang sama-sama kita hormati. Pelaksana tugas Kepala desa, para perangkat desa, Babinsa, Babinkaptipmas, tokoh-tokoh masyarakat, rekan-rekan panitia, sahabat-sahabat remaja masjid Baiturrohim Siwalan Panji, sahabat-sahabat Ansor, sahabat-sahabat Banser. Hadirin Bapak Ibu, muda-mudi para jamaah dalam rangka hormat peringatan Maulid Nabi Agung Muhammad SAW.

Data tersebut merupakan data penggunaan bahasa Indonesia oleh K.H. Anwar Zahid dalam ceramahnya. Bahasa Indonesia digunakan karena ceramah disampaikan dalam situasi yang resmi. Resmi, artinya ceramah tersebut disampaikan dalam rangka pengajian umum untuk memperingati Maulid Nabi SAW yang diselenggarakan oleh remaja Masjid Baiturrohim, bertempat di Desa Siwalan Panji, Kecamatan Buduran, Kabupaten Sidoarjo, yang dihadiri oleh Camat, Lurah, dan perangkat kecamatan yang lain. Oleh karena itu, K.H Anwar Zahid dalam sambutan resmi menggunakan bahasa Indonesia. Pada tuturan tersebut tidak terjadi pergantian kode, baik berupa alih kode maupun campur kode. Penceramah dari awal hingga akhir tetap menggunakan bahasa Indonesia. Penceramah menggunakan bahasa Indonesia untuk menyapa terutama kepada khalayak yang pada saat itu hadir. Penceramah beretnik Jawa dan khalayak juga beretnik Jawa, tetapi penceramah dalam menyapa khalayak menggunakan bahasa Indonesia dikarenakan memang acara pengajian umum ini acara formal, sehingga penceramah menyapa kepada khalayak menggunakan bahasa Indonesia.

Penggunaan bahasa disebabkan oleh alasan yang hadir dalam pengajian tersebut tidak hanya dari kalangan masyarakat umum, tetapi juga dari kalangan aparatur pemerintahan, serta kalangan pemuda. Penceramah dalam menyapa khalayak menggunakan bahasa Indonesia karena bahasa Indonesia merupakan bahasa yang juga dipahami oleh kalangan masyarakat, dari masyarakat kelas sosial tinggi maupun kelas sosial menengah ke bawah yang pada saat itu hadir dalam pengajian tersebut. Dari konteksnya diketahui bahwa penggunaan bahasa 
ditujukan untuk menghormati dan tidak membedakan antara kalangan masyarakat biasa, kalangan pemerintahan dan kalangan pemuda.

Penggunaaan bahasa Arab pada ceramah agama oleh K.H. Anwar Zahid tampak pada kutipan berikut.

Konteks: ceramah K.H. Anwar Zahid disampaikan dalam pengajian umum di Taman Buah, Pasar Kemis, Tangerang, sebagai pembuka ceramah.

Tuturan: Assalamualaikum warohmatullohi wabarokatuh. Bismillahirrohmanirrohim. Alhamdulillahi wahdah. Sodaqohhu wahdah. Wanasoro wahdah. Waiaszamdudah....

Dari kutipan data yang dicontohkan ini diketahui bahwa bahasa yang digunakan oleh K.H. Anwar Zahid pada saat pembukaan ceramah adalah bahasa Arab. Demikian pula ketika memimpin doa sebagai penutup ceramah, menggunakan bahasa Arab. Dalam berdoa sebagai penutup ceramah, K.H. Anwar Zahid menggunakan bahasa Arab. Penggunaan bahasa Arab dalam segmen penutup ceramah tampak pada kutipan data berikut ini.

Konteks: ceramah K.H. Anwar Zahid disampaikan dalam pengajian umum di Taman Buah, Pasar Kemis, Tangerang, ketika memimpin doa sebagai penutup ceramah.

Tuturan: ...Khama ila Syeh Abdul Qodir Jaelani...robbanna attina fidun ya khasanah, wafil akhirati khasanah, waqina adzabanaar...Subkhanaka robbika robbil izati ama yaasifuun, wasalamun alal mursalin, walkhamdulillahirobbil alamin....

Bahasa yang tampak khas pada ceramah K.H Anwar Zahid adalah digunakannya unsur dasar bahasa daerah (Jawa) dan imbuhan bahasa Indonesia. Hal ini seperti tampak pada kutipan data berikut ini.

Konteks: ceramah K.H. Anwar Zahid ketika peringatan Maulud Nabi di Pondok Pesantren Roudhatul Ulmu, Pati, Jawa Tengah.

Tuturan: ...itu adalah kebiasaan yang harus di-kulinak-kan. Maksudnya adalah, itu harus dilatihkan secara terus-menerus, sehingga menjadi kebiasaan....

Selain itu, K.H. Anwar Zahid dalam ceramahnya menggunakan bahasa berirama. Bahasa berirama yang digunakan tampak pada kutipan data berikut ini.

Konteks: ceramah disampaikan oleh K.H. Anwar Zahid ketika diundang untuk pengajian umum di Pati, Jawa Tengah, yang jamaahnya adalah warga perantuan TKI dari Malaysia dan masyarakat umum.

Tuturan: ...orang jaman sekarang, nyandang rapet, mangan wareg, turu anget, mlaku cepet, dompet padhet. 

Rochiyati S.)

Kata di-kulinak-kan adalah adalah kata yang dibentuk oleh dua unsur, yaitu kata asal dan imbuhan. Kata asalnya adalah kata bahasa Jawa, sedangkan imbuhannya, yaitu awalan $\{$ di- $\}$ dan akhiran $\{-k a n\}$ adalah imbuhan bahasa Indonesia. Bentukan ini tidak lazim digunakan oleh orang dalam berbahasa Indonesia, tetapi tampaknya sengaja digunakan oleh K.H. Anwar Zahid dalam ceramahnya, sehingga menimbulkan gelak tawa para jamaah. Demikian pula, agar para jamaahnya tidak bosan, dalam ceramahnya, K.H. Anwar Zahid menggunakan bahasa berirama. Penggunaan bahasa berirama tampak pada digunakannya kata-kata berakhiran et, seperti, rapet, wareg, anget, cepet, dan padhet.

\section{Faktor Penentu Penggunaan Bahasa dalam Ceramah Agama oleh K.H. Anwar Zahid}

Berdasarkan data yang didapatkan diperoleh keterangan bahwa terdapat faktor-faktor yang melatarbelakangi penggunaan bahasa ceramah agama oleh K.H. Anwar Zahid. Faktorfaktor yang mempengaruhi penggunaan bahasa yang digunakan K.H. Anwar Zahid adalah faktor latar (setting). Faktor latar yang melatarbelakangi penggunaan bahasa oleh K.H. Anwar Zahid tampak pada kutipan data berikut.

Konteks: tuturan ini disampaikan oleh K.H. Anwar Zahid dalam rangka pengajian umum untuk memperingati Israj Miraj Nabi Muhammad SAW pada tanggal 1 April 2018 bertempat di Perum Griya Ijen Mojokerto.

Tuturan: "Sama saja sami mawon, [ ...sami mawon] tapi orang yang hidupnya berkah itu selalu ada dinamika ke arah hidup yang lebih baik.

'Sama saja sama saja, tapi orang yang hidupnya berkah itu selalu ada dinamika ke arah hidup yang lebih baik'.

Kutipan tersebut menunjukkan bahwa dalam berceramah, K.H. Anwar Zahid melakukan campur kode, yaitu mencampur kode bahasa Indonesia dengan bahasa Jawa, sami mawon. Dari konteksnya diketahui bahwa melakukan campur kode ditujukan untuk menyesuaikan dengan latar (setting) ceramah. Oleh karena latar ceramah ada di Mojokerto, yang jamaahnya adalah orang Jawa, maka campur kode yang dilakukan adalah campur kode bahasa Jawa. Dengan demikian, faktor latar menjadi penentu penggunaan bahasa. kode bahasa Jawa

Selanjutnya, faktor lain yang juga menjadi penentu pilihan bahasa oleh K.H Anwar Zahid adalah faktor peserta pengajian atau partisipan (participants). Oleh karena partisipannya adalah orang Jawa, meskipun ceramah disampaikan dalam bahasa Indonesia, diselingi dengan penggunaan bahasa Jawa. Hal ini seperti tampak pada kutipan data berikut.

Konteks: Tuturan ini disampaikan oleh K.H. Anwar Zahid dalam rangka Pengajian Umum untuk Memperingati Israj Miraj Nabi Muhammad SAW pada tanggal 1 April 2018 bertempat di Perum Griya Ijen Mojokerto. Pengajian banyak dihadiri oleh muslimah, terutama ibu-ibu.

Tuturan: "Apalagi ketika masih kecil, itu saat pembentukan karakter nggeh [...ngeh] Bu nggeh"[ ...nggeh].

'Apalagi ketika masih kecil, itu saat pembentukan karakter ya Bu, ya'. 
Dalam kutipan tersebut tampak bahwa ada peristiwa campur kode yang dilakukan oleh K.H. Anwar Zahid dalam ceramahnya. Dalam berbahasa Indonesia, "Apalagi ketika masih kecil, itu saat pembentukan karakter Bu...", diselingi penggunaan kode bahasa Jawa "nggeh". Menurut Kamus bahasa Jawa (Purwadi, 2004:113) "nggeh" dalam bahasa Indonesia artinya 'ya'. Artinya, K.H. Anwar Zahid dalam ceramahnya melakukan campur kode bahasa Jawa ke dalam bahasa Indonesia. Hal ini ditandai dengan memasukkan bahasa Jawa "nggeh" ke dalam bahasa Indonesia. Bahasa Jawa yang digunakan oleh K.H. Anwar Zahid adalah bahasa Jawa Krama. Hal ini didorong oleh karena penceramah ingin menghormati pendengar ibu-ibu yang usianya di atas penceramah. Oleh karena partisipan yang dihadapi dalam ceramah adalah ibuibu Jawa, maka penceramah menggunakan bahasa Jawa Krama. Dari konteksnya, diketahui bahwa faktor-faktor yang menyebabkan K.H. Anwar Zahid di dalam menyampaikan ceramahnya melakukan campur kode bahasa Jawa Krama karena adalah faktor partisipan tutur.

Faktor tujuan (ends) tutur merupakan salah satu penentu pemilihan bahasa yang digunakan oleh K.H. Anwar Zahid dalam ceramahnya. Berikut adalah data yang mendukung pernyataan ini.

Konteks: ceramah K.H. Anwar Zahid ketika peringatan Maulud Nabi di Pondok Pesantren Roudhatul Ulmu, Pati, Jawa Tengah.

Tuturan: ...itu adalah kebiasaan yang harus di-kulinak-kan. Maksudnya adalah, itu harus dilatihkan secara terus-menerus, sehingga menjadi kebiasaan....

Selain itu, K.H. Anwar Zahid dalam ceramahnya menggunakan bahasa berirama. Bahasa berirama yang digunakan tampak pada kutipan data berikut ini.

Konteks: ceramah disampaikan oleh K.H. Anwar Zahid ketika diundang untuk pengajian umum di Pati, Jawa Tengah, yang jamaahnya adalah warga perantauan TKI dari Malaysia dan masyarakat umum.

Tuturan: ...orang jaman sekarang, nyandang rapet, mangan wareg, turu anget, mlaku cepet, dompet padhet.

Dari konteksnya diketahui bahwa digunakannya kata bentukan dengan unsur dasar bahasa daerah (Jawa) dan imbuhan bahasa Indonesia, di-kulinak-kan dan digunakannya katakata berirama atau ber-rima, et, eg, et, et, dan et, ditujukan untuk menimbulkan kesan lucu dan humor. Dengan demikian, tujuan tuturan mendorong dipilihnya bahasa tertentu dalam ceramah K.H. Anwar Zahid.

\section{SIMPULAN}

Dari analisis data yang telah dilakukan dapat disimpulkan bahwa bahasa yang digunakan dalam ceramah agama oleh K.H. Anwar Zahid pada umumnya adalah bahasa Indonesia dan bahasa Arab. Bahasa Indonesia terutama digunakan untuk menyampaikan isi ceramah, sedangkan penggunaan bahasa Arab terutama digunakan pada segmen pembuka ceramah dan segmen doa penutup ceramah. Selain itu, di dalam memberikan ceramah beliau 
sering kali menyelipkan unsur-unsur bahasa lain. Unsur bahasa lain tersebut adalah bahasa Jawa Ngoko, bahasa Jawa Krama, bahasa Arab. Dengan demikian, dalam bahasa yang digunakan oleh K.H. Anwar Zahid ketika berceramah terdapat peristiwa campur kode dan alih kode. Faktor yang melatarbelakangi penggunaan bahasa dalam ceramah agama oleh K.H. Anwar Zahid adalah faktor latar (setting), faktor partisipan (participant), dan faktor tujuan tutur (ends of speech).

\section{DAFTAR PUSTAKA}

Al-Munawwir. 2002. Kamus Arab, Arab-Indonesia Terlengkap. Surabaya: Pustaka Progressif.

Badan Pengembangan dan Pembinaan Bahasa. 2016. KKBI V 0.2.1 Beta (21). Jakarta: Kemendikbud RI.

Chaer, A. dan Agustina, L. 2014. Sosiolinguistik: Perkenalan Awal. Jakata: Rineka Cipta.

Khadafi. 2009. "Pemakaian Bahasa pada Ceramah Agama Majelis Sholawatan Al-Ghofilin Kabupaten Jember". Skripsi. Jember: Jurusan Sastra Indonesia, Fakultas Sastra, Universitas Jember.

Mahsun. 2005. Metode Penelitian Bahasa: Tahapan Strategi, Metode, dan Tekniknya. Jakarta: Raja Grafindo Persada.

Purwadi. 2004. Kamus Jawa, Jawa-Indonesia. Yogyakarta: Media Abadi.

Rahayuningsih, E. 2013 “Tindak Tutur Representatif dalam Ceramah K.H. Anwar Zahid”. Skripsi. Jember: Jurusan Pendidikan Bahasa dan Seni, Fakultas Keguruan dan Ilmu Pendidikan, Universitas Jember.

Schiffrin, D. 1994. Approaches to Discourse. Cambridge: Blackwell Publishers

Sudaryanto. 1993. Metode dan Aneka Teknik Analisis Bahasa. Yogyakarta: Duta Wacana University Press.

Sutardi. 1994. "Gejala Campur Kode dalam Ceramah Agama K.H. Zainuddin M.Z.”. Skripsi. Jember: Jurusan Sastra Indonesia, Fakultas Sastra, Universitas Jember. 